University of Nebraska - Lincoln

DigitalCommons@University of Nebraska - Lincoln

1992

\title{
Local Polyploid Variation in the Native Prairie Grass Andropogon gerardii
}

Kathleen H. Keeler

University of Nebraska - Lincoln, kkeeler1@unl.edu

Follow this and additional works at: https://digitalcommons.unl.edu/bioscifacpub

Part of the Biodiversity Commons, Botany Commons, Plant Biology Commons, and the Plant Breeding and Genetics Commons

Keeler, Kathleen H., "Local Polyploid Variation in the Native Prairie Grass Andropogon gerardii" (1992). Faculty Publications in the Biological Sciences. 288.

https://digitalcommons.unl.edu/bioscifacpub/288

This Article is brought to you for free and open access by the Papers in the Biological Sciences at DigitalCommons@University of Nebraska - Lincoln. It has been accepted for inclusion in Faculty Publications in the Biological Sciences by an authorized administrator of DigitalCommons@University of Nebraska - Lincoln. 


\title{
LOCAL POLYPLOID VARIATION IN THE NATIVE PRAIRIE GRASS ANDROPOGON GERARDII'
}

\author{
KATHLEEN H. KeEleR ${ }^{2}$ \\ School of Biological Sciences, University of Nebraska-Lincoln, Lincoln, Nebraska 68588-0343
}

\begin{abstract}
The microscale distribution of polyploid variants of the dominant grass big bluestem (Andropogon gerardii) in virgin tallgrass prairie was mapped using flow cytometry. The correlation between DNA content and polyploidy allows the use of flow cytometry for nondestructive determination of polyploidy in intact plants. At Konza Prairie, local plots contained from 0 to $100 \%$ hexaploid cytotypes but most showed fine-scale mixing of the polyploid variants. The relationship of cytotype frequency to moisture availability or burning history was nonsignificant.
\end{abstract}

Genetic variation is basic to evolutionary change. Intraspecific variation in polyploidy is a widespread, although not widely studied, form of genetic variation in natural plant populations (e.g., Lewis, 1980; Keeler and Kwankin, 1989). Investigating polyploid variation within populations has been time-consuming and may require disturbing the site. However, the advent of flow cytometry has made nondestructive study of the level of nuclear DNA, and therefore, chromosome numbers, possible for large populations (Keeler et al., 1987; Fahleson et al., 1988; Sgorbati et al., 1989; Michaelson et al., 1991). It is now possible to determine rapidly the local distribution of intraspecific polyploidy for intact plants in the vegetative state. This paper reports the results of using flow cytometry to map the distribution of cytotypes in a natural population of a dominant prairie grass, providing a detailed look at the cytogenetic structure of natural populations.

Big bluestem, Andropogon gerardii Vitman, is the dominant grass of the tallgrass prairie (Weaver and Fitzpatrick, 1934). This species contains chromosomal variation: in addition to the commonly reported hexaploids $(2 n=6 \mathrm{x}$ $=60$; Gould, 1967) populations include individuals that are 7x, 8x, and 9x (Kwankin, 1985; Keeler et al., 1987; Keeler, 1990). Of these, $2 n=60$ and 80 are by far the most common cytotypes (Keeler et al., 1987; Keeler, 1990).

In a geographic study across the northern tallgrass prairie (Ohio to Nebraska), octoploid and nonoploid plants were found chiefly in the western part of the transect, where they reached $82 \%$ of one Nebraska prairie remnant (Keeler et al., 1987; Keeler, 1990, and unpublished data).

Forces producing macrogeographic polyploid variation should operate locally as well. Thus, the microgeographic distribution of $A$. gerardii cytotypes was sought within a site rich in edaphic variation. Patterns of microgeographic variation in distribution of polyploids were sought in response to available moisture, burn treatment, and grazing. In this paper, I report the small-scale distribution of poly-

\footnotetext{
' Received for publication 25 February 1992; revision accepted 3 August 1992.

The author thanks K. Harkins, D. W. Galbraith, C. L. Johnson, and W. F. Wade for flow cytometry; Konza LTER for logistical support; D. Marx for important statistical advice; K. Taylor, S. Gaines, and K. Anderson for assistance with the field work; and L. S. Vescio for work on the figures. This project was supported by an NSF-LTER supplement to NSF grant BSR 87-04705.

${ }^{2}$ FAX: 402-472-8722.
}

ploid cytotypes of $A$. gerardii within Konza Prairie, Manhattan, Kansas.

\section{MATERIALS AND METHODS}

Located south of Manhattan, Kansas, Konza Prairie is a 3,487-ha tallgrass prairie reserve (owned by The Nature Conservancy, managed by Kansas State University). Annual rainfall is $834 \mathrm{~mm}$ (National Oceanographic and Atmospheric Commission, 1985). Upland soils are Florence cherty clay loam, and lowland soils are Tully silty clay loams (Jantz et al., 1975). The new focus of research at Konza is on the role of fire and grazing in the dynamics of tallgrass prairie. Burning treatments were initiated in 1971.

The plots for this project were established to take advantage of relief and burning treatments. Three replicates each on wet and dry edaphic sites were nested within the extreme burning treatments: annually burned and unburned ( 20 years between fires) treatments. Hillside relief (elevations range from 320 to $444 \mathrm{~m}$ ) provided natural wet and dry areas within the prairie. Specifically, the shallow soils on the hilltops are xeric; whereas seepage through the stratified rocks produces moist areas at the base of hills where water percolates out of the strata and flows downward toward streams (E. Finck, Emporia State University, personal communication). Wet and dry plots were also established in areas into which native grazers (Bison bison) were reintroduced in 1987 . The grazed plots were established only on annually burned sites within the bison area, which turned out to be the most intensely grazed areas, because of the strong preference of the bison for burned sites (Bock and Bock, 1989; Shaw and Carter, 1990; Vinton, 1990). The sites are located in UA, UB, UD, 1 A, 1 B, 1D, and N1 A in Konza nomenclature. Konza is a National Science Foundation Long Term Ecological Research Site.

Plants were permanently marked in May 1989 , with an aluminum tag held by a nail and a ring of plastic-wrapped wire. Sampled plants were chosen ca. $1 \mathrm{~m}$ apart, to reduce the frequency of sampling the same genetic individual. Nearest-neighbor and mapping data were used to test this assumption. Plants were sampled for flow cytometry during the summers of 1989 and 1990.

Sample size was chosen to identify 20 individuals of one cytotype at each site. Because more than ten plants per site were collected for flow cytometry at the same time, most plots ended up with approximately 30 cyto- 

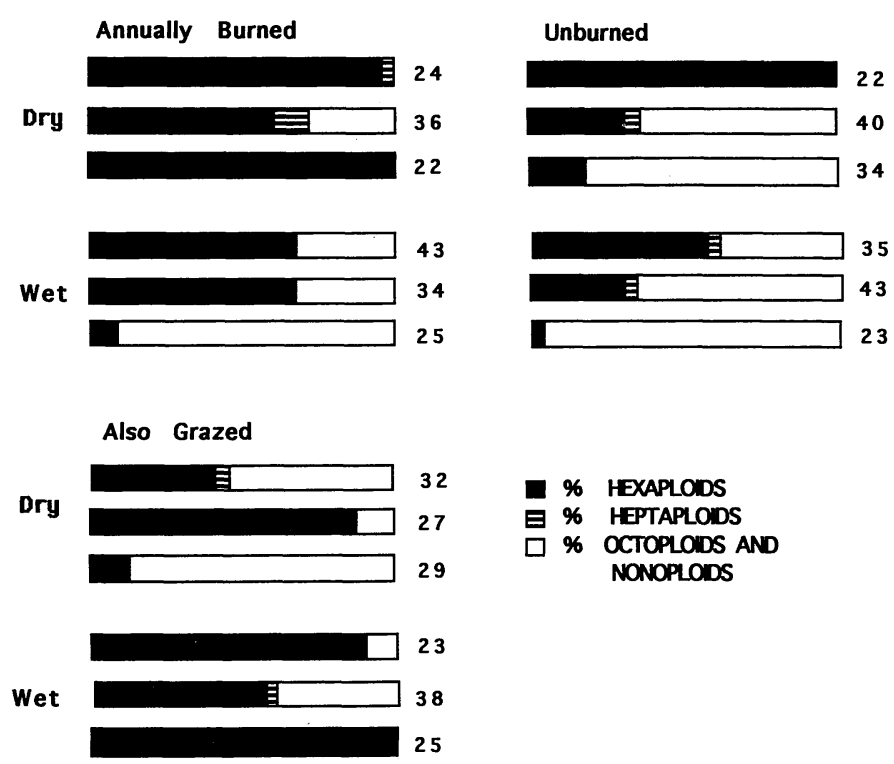

Fig. 1. Distribution of cytotypes within treatment plots at Konza Prairie. Each bar represents a replicate plot. Number is number of plants sampled.

typed plants. The plants sampled were at least a meter apart, in two to four rows; therefore the plots range from $4 \times 10 \mathrm{~m}$ to $6 \times 20 \mathrm{~m}$ in size.

In 1989, fresh leaf tissue was collected and sent overnight mail to D. W. Galbraith, University of Arizona, Tucson, for analysis. In 1990, plants were analyzed at the University of Nebraska-Lincoln flow cytometry facility.

Flow cytometry preparation methods followed Keeler et al. (1987). Fresh leaves were chopped in the cold with a razor blade, $0.3 \mathrm{~g}$ tissue to $5 \mathrm{ml}$ chopping buffer $(45 \mathrm{ml}$ $\mathrm{MgCl}_{2}, 30 \mathrm{~mm} \mathrm{Na}$ citrate, $20 \mathrm{~mm}$ MOPS pH 7.0, containing $1 \mathrm{mg} / \mathrm{ml}$ triton X-100) in a glass dish. After standing $2 \mathrm{~min}$, cellular debris was filtered through nylon mesh of pore size $60 \mu \mathrm{m}$ and $15 \mu \mathrm{m}$. Nuclei in the filtrate were then stained with $\times 9$ excess of $100 \mu \mathrm{g} / \mathrm{ml}$ mythramycin in chopping buffer and let stand 5-60 min. DNA content was analyzed by detection of stain from nuclei in a Coulter Electronics EPICS V Flow Cytometer-Cell Sorter, laser wavelength $457 \mathrm{~nm}$, power output of $200 \mathrm{~mW}$, using barrier filters LP510 and BG38 for optimal detection of the mythramycin-DNA complex.

DNA values were calculated by comparison to chicken red blood cell internal standards, which have $2.33 \pm 0.22$ pg DNA/nucleus (Galbraith et al., 1983). Mythramycin binds to guanine-cytocine base pairs, so the numerical values are more accurate as ratios than absolute DNA values. Controls run with DAPI and Hoechst (which bind adenine-thymine pairs) gave identical ratios between the low and high DNA cytotypes studied here (Keeler, Galbraith, and Harkins, unpublished data).

Replicability of flow cytometric values is high: the between-run, between-day, and between-tissue errors are all approximately the level of machine error and much less than the DNA differences between most cytotypes (Keeler et al., 1987).

As controls, chromosome numbers were counted under the microscope from root tips of 123 plants. A variety of plants were used in these studies, only a few of them from Konza Prairie. In wild collected plants no chromosome numbers other than multiples of the base number $(x=$ 10) were seen, although visual counting uncertainties suggest the error is \pm two chromosomes. These values were compared to flow cytometric values for those same plants.

Hexaploids had a mean of $7.17 \mathrm{pg}$ nuclear DNA (SD $=0.75, N=46$ ). Heptoploid plants had $8.64 \mathrm{pg}$ DNA $(\mathrm{SD}=0.32, N=4)$. Octoploids averaged $10.04 \mathrm{pg}$ nuclear DNA (SD $=0.84, N=28$ ). Nonoploids had a mean of $10.34 \mathrm{pg}$ DNA (SD $=0.30, N=15)$. All groups were statistically significantly different from all others (Duncan's test) except octoploids and nonoploids. Cytological studies are in progress to distinguish octoploids and nonoploids by flow cytometry (Norrmann and Keeler, unpublished data). The difficulty in distinguishing the octo- and nonoploids appears to be specific to Andropogon gerardii since other species investigated have no such problem (e.g., Galbraith et al., 1983; Sgorbati et al., 1989; de Rocher et al., 1990; Keeler, unpublished data). Analysis of variance for chromosome number by flow cytometric value also showed a highly significant relationship of the two $(F=305, P<0.0001$, df $=92)$. This analysis is an extension and refinement of previously reported comparisons and is consistent with previous results (Keeler et al., 1987).

A finding of 6.5-7.5 pg DNA ("low DNA") is absolutely diagnostic of 60 chromosome plants. The low DNA plants are clearly distinguishable from "high DNA" plants: those have approximately $10 \mathrm{pg}$ nuclear DNA, and always a different chromosome number. The high DNA group includes both octoploids and nonoploid plants as noted above. Intermediate DNA values (ca. $8 \mathrm{pg}$ ) indicate plants with $2 n=70$ : only 12 of the 554 plants collected at Konza Prairie in this study, 2\%, had 8 pg DNA.

Nearest neighbor analysis was conducted by measuring the distance to the nearest plant and the nearest $A$. gerardii in four ordinal directions from the marked plant in four plots, one each of wet/dry, burned/unburned combinations.

Data were statistically analyzed using the analysis of variance in the SAS general linear models (GLM) program (SAS Institute, Inc., 1989) on arcsin-transformed percent low DNA. Because the grazing treatment was only on annually burned treatments, grazing was treated in the statistical analysis as a third burn treatment, not as a third independent variable.

\section{RESULTS}

Of the 18 sites at Konza Prairie, 14 contained both high and low DNA $A$. gerardii plants and 12 are polymorphic for polyploidy in the sense that the rarest cytotype forms more than 5\% of the population (sensu Dobzhansky et al., 1977). Within sites, frequency of low DNA plants ranged from $3 \%$ to $100 \%$ (Fig. 1). Sites within the same treatment vary greatly (Fig. 1), thus it is not surprising that analysis of variance showed no significant effects of treatment on cytotype distribution (for burning treatment $F=1.01, P=0.39, \mathrm{df}=2$; for moisture $F=0.14, P=$ 0.71 , df $=2$; for burning $\times$ moisture effects $F=3.71, P$ $=0.06, \mathrm{df}=1$ ). 


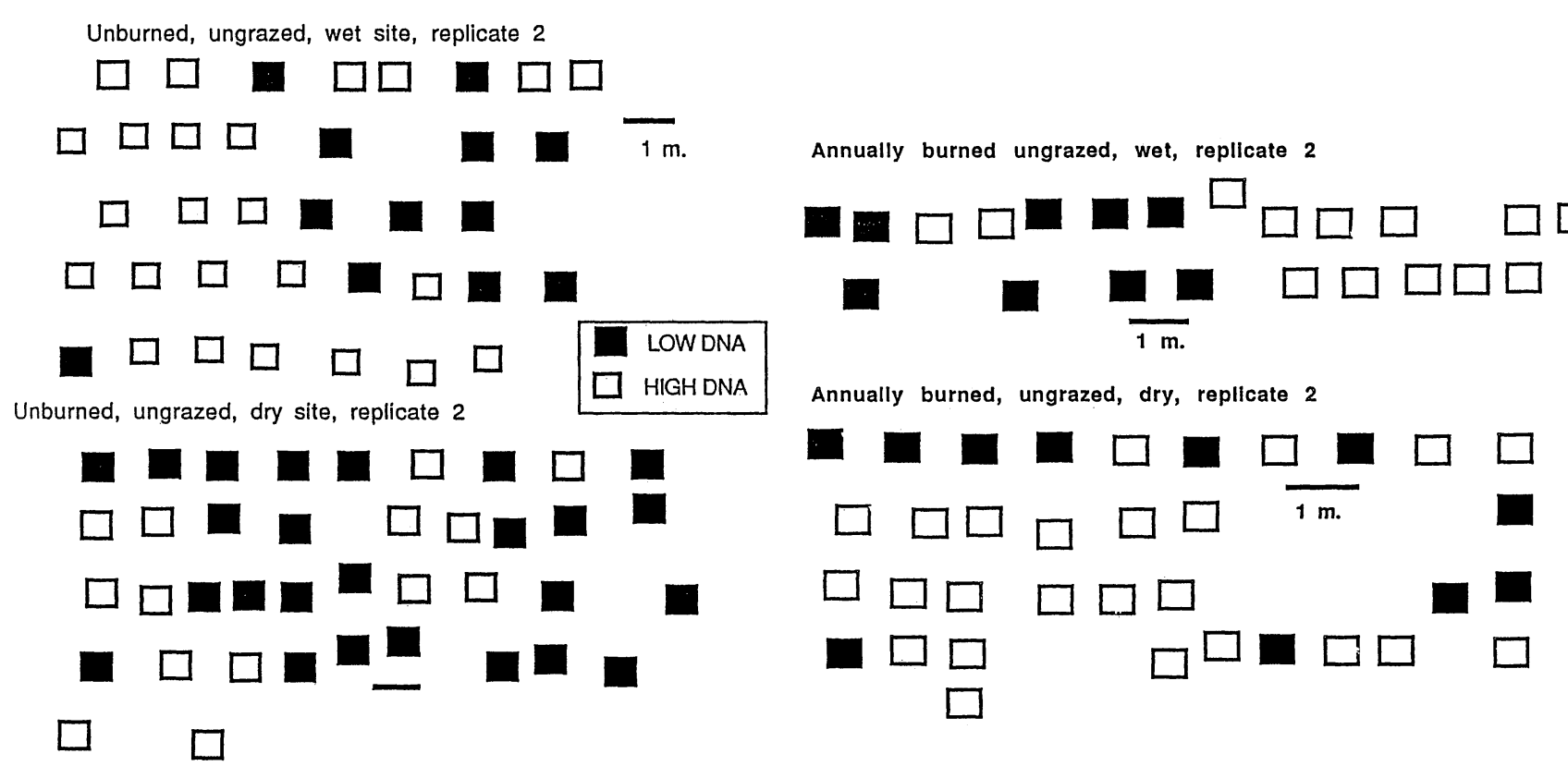

Fig. 2. Distribution of cytotypes within plots at Konza Prairie. Four representative plots are shown. Each square represents a permanently marked plant.

The within-site mixing of cytotypes was striking. The two cytotypes are interspersed on most sites (Fig. 2). Across the study, the chance of finding the next cytotyped plant (ca. $1 \mathrm{~m}$ away) to have a different cytotype ranged from 0.0 on the monomorphic plots to 0.44 on the most varied. The theoretical maximum is 0.5 for a population of alternating cytotypes.

Nearest neighbor analysis of four representative plots found the nearest $A$. gerardii to each marked plant to be $61.4,28.4,23.6$, and $30.7 \mathrm{~cm}$ away, while marked plants averaged $1 \mathrm{~m}$ apart. Furthermore, the nearest neighbor of each plant is generally not another plant of $A$. gerardii: the plant of any species nearest the marked plants in the four plots above was $8.9,8.6,16.1$, and $13.4 \mathrm{~cm}$ away, respectively-much less than the distance to the nearest A. gerardii. A long history of clonal spread is possible, but at present $A$. gerardii populations are made of many discontinuous clumps.

\section{DISCUSSION}

Plant species can include virtually indistinguishable individuals with different chromosome numbers (e.g., Nielsen, 1944; Zohary and Nur, 1959; Gould and Kapadia, 1964; Porter, 1966; Lewis, Suda, and MacBryde, 1967; Stuessy, 1971; Brunken and Estes, 1975; Lewis, 1980; Lumaret, 1988). Flow cytometry offers a nondestructive method for getting substantial sample sizes of chromosomal variants, including polyploid series, in large populations. Not only are several polyploid cytotypes of $\mathrm{An}$ dropogon gerardii present at Konza Prairie, they intermingle at most locations, indicating genetic variation in this character at a very fine scale.

None of the treatments at Konza showed a statistically significant relationship to cytotype. Lack of response to grazing was not surprising, since bison were reintroduced in 1987. No relation to the older treatments, burning regime (initiated 1971), and water availability was found either. The suggestion of interaction of burn treatment and moisture $(P=0.06)$ is considered nonsignificant and not indicative of a trend because the data is in the opposite direction of biogeographic patterns. Hexaploids are more frequent on dry, burned sites at Konza, while hexaploids totally dominated eastern tallgrass prairie remnants previously studied (Keeler, 1990), which are moister, if not less often burned, than western prairies (Keeler, 1990). Different cytotypes usually intermingle where they occur elsewhere in the range of $A$. gerardii (Keeler, 1990 and unpublished data). Big bluestem populations have a complex cytogenetic structure, but no simple relation to environmental variables has been detected.

A random or historical explanation of the distribution of cytotypes within and between sites at Konza seems the most likely, based on current data. This would suggest functional equivalence. Functional equivalence of hexaploids and octoploids may be reasonable for the following reasons: electrophoretic patterns of plants (six stain systems, 12-15 loci) reveal no bands or band patterns that distinguish different chromosome numbers (Keeler et al., unpublished data); individual plants regularly produce progeny that segregate for cytotype, e.g., hexaploid, octoploid, and nonoploid plants in the progeny of hexaploid, octoploid, or nonoploid parents (Norrmann and Keeler, unpublished data); and, except for subtle but consistent differences in size, the polyploids are not morphologically distinguishable (Keeler, unpublished data).

Countering the interpretation that ploidy level is functionally neutral is the observation that hexaploids are virtually the only cytotype across central North America (Keeler, 1990) even though octoploids and nonoploids are present at the extremes of the range (eastern Nebraska and northern Florida, Keeler, 1990 and unpublished data). In addition, higher polyploids are consistently, if not al- 
ways statistically significantly, taller and of higher biomass than hexaploids (Keeler, unpublished data).

The higher polyploids are not due to hybridization occurring at the edge of the range. The only other hexaploid Andropogon in North America, A. hallii, possesses the same variation in chromosomes: three populations were fixed for $7 \mathrm{pg}$ DNA (hexaploids), one for $10 \mathrm{pg}$ DNA (octoploids or nonoploids), $N=71$ (Keeler, unpublished data). That the variation represents the replacement of one polyploid level by another seems unlikely, because of two populations studied at the southeastern corner of the range (Apalachicola National Forest, FL), one was fixed for $7 \mathrm{pg}$ DNA and one for $10(N=29)$ (Keeler, unpublished data), so polyploid variation is found from one end of the species range to the other (Keeler, 1990).

Despite its economic importance, $A$. gerardii is virtually unknown genetically, so breeding system and compatibility between the cytotypes are not understood. Studies on those topics are in progress. Meiosis is regular in hexaploid plants (Riley and Vogel, 1982; Norrmann, personal communication), irregular in other cytotypes (Norrmann, personal communication), and shows numerous lagging chromosomes reminiscent of South American Andropogon ternatus (Norrmann and Quarin, 1987). All cytotypes produce some viable seed.

The chromosomal variation in $A$. gerardii is representative of chromosomal variation in other important prairie grasses, e.g., Panicum virgatum (Nielsen, 1944; Porter, 1966; Brunken and Estes, 1975), Bouteloua curtipendula (Gould and Kapadia, 1964), B. gracilis (Snyder and Harlan, 1953), Agropyron smithii (Dewey, 1975), and others (Stebbins, 1971, 1975; Keeler and Kwankin, 1989) suggesting a common, perhaps evolutionary, response. Whatever polyploid variation does, flow cytometric studies show that it occurs on a very local scale in the prairie dominant $A$. gerardii.

\section{LITERATURE CITED}

Bock, J. H., AND C. E. Bock. 1989. Ecology and evolution in the Great Plains. In J. H. Bock and Y. B. Linhart [eds.], The evolutionary ecology of plants, 551-579. Westview Press, Boulder, CO.

BRUNKEN, J. N., AND J. R. Estes. 1975. Cytological and morphological variation in Panicum virgatum $\mathrm{L}$. The Southwestern Naturalist 19: 379-385.

DE Rocher, E. J., K. R. HARkins, D. W. Galbraith, AND H. J. Bohnert. 1990. Developmentally regulated systematic endopolyploidy in succulents with small genomes. Science 250: 99-101.

DEWEY, D. R. 1975. The origin of Agropyron smithii. American Journal of Botany 62: 524-530.

Dobzhansky, T., F. J. Ayala, G. L. Stebbins, and J. W. Valentine. 1977. Evolution. W. H. Freeman, San Francisco, CA.

Fahleson, J., J. Dixelius, E. Sundberg, and K. Glimelius. 1988. Correlation between cytometric determination of nuclear DNA content and chromosome number in somatic hybrids within Brassicaceae. Plant Cell Report 7: 74-77.

Galbraith, D. W., K. R. Harkins, J. M. Maddox, N. M. Ayres, D. P. Sharma, AND E. Firoozabady. 1983. Rapid flow cytometric analysis of the cell cycle in intact plant tissues. Science 220: 10491051.

Gould, F. W. 1967. The genus Andropogon in the United States. Brittonia 19: 70-76.
- AND Z. J. Kapadia. 1964. Biosystematic studies in the Bouteloua curtipendula complex. II. Taxonomy. Brittonia 16: 182-207.

Jantz, D. R., R. F. HanNer, H. T. Rowland, AND D. A. Gier. 1975. Soil survey of Riley Co. and part of Geary Co., Kansas. USDA Soil Conservation Service and Kansas State University Agricultural Experiment Station, Manhattan, KS.

KeELER, K. H. 1990. Distribution of polyploid variation in big bluestream (Andropogon gerardii Poaceae) across the tallgrass prairie region. Genome 33: 95-100.

- AND B. KWANKIN. 1989. Polyploid polymorphism in grasses of the North American prairie. In J. H. Bock and Y. B. Linhart [eds.], The evolutionary ecology of plants, 99-128. Westview Press, Boulder, CO.

,-- P. W. Barnes, and D. W. Galbraith. 1987. Polyploid polymorphism in Andropogon gerardii. Genome 29: 374-379.

KwankIn, B. 1985. Polyploidy in Andropogon gerardii (Poaceae): its effect on distribution, morphology, development and DNA content. M.S. thesis, University of Nebraska-Lincoln. Lincoln, NE.

Lewis, W. H. [ed.]. 1980. Polyploidy. Biological relevance. Plenum Press, New York, NY.

- Y. Yuda, AND B. MacBryde. 1967. Chromosome numbers of Claytonia virginica of the St. Louis, Missouri area. Annals of the Missouri Botanical Garden 54: 147-152.

Lumaret, R. 1988. Cytology, genetics and evolution in the genus Dactylis. CRC Critical Reviews of Plant Science 7: 55-91.

Michaelson, M. J., H. J. Price, J. R. Ellison, and J. S. Johnston. 1991. Comparison of plant DNA contents determined by Feulgen microspectrophotometry and laser flow cytometry. American Journal of Botany 78: 183-188.

NATIONAL OCEANOGRAPHIC AND AtMOSPHERIC COMmission. 1985. Climatic records: Kansas, vol. 99(13), 1-33. National Climatic Data Center, Asheville, NC.

Nielsen, E. L. 1944. Analysis of variation in Panicum virgatum. Journal of Agricultural Research 69: 327-353.

Norrmann, G. A., AND C. A. Quarin. 1987. Permanent odd polyploidy in a grass (Andropogon ternatus). Genome 29: 340-344.

PorTer, C. L. 1966. An analysis of variation between upland and lowland switchgrass Panicum virgatum in central Oklahoma. Ecology 47: 980-992.

Riley, R. D., AND K. P. Vogel. 1982. Chromosome numbers of released cultivars of switchgrass, indiangrass, big bluestem and sand bluestem. Crop Science 22: 1081-1083.

SAS INSTITUTE, INC. 1989. SASSTAT user's guide. SAS Institute, Cary, NC.

Sgorbati, S., S. M. Masci, V. Soler, and P. Marchi. 1989. Rapid cytofluorometric determination of leaf nuclear DNA in the polyploid series Ranunculus marsicus ( $R$. auricomus agg., Ranunculaceae). Plant Systematics and Evolution 167: 219-226.

Shaw, J. H., AND T. S. CARTER. 1990. Bison movements in relation to fire and seasonality. Wildlife Society Bulletin 18: 426-430.

SNYDER, L. A., AND J. R. HARLAN. 1953. A cytological study of Bouteloua gracilis from western Texas and eastern New Mexico. American Journal of Botany 40: 702-707.

Stebirs, G. L. 1971. Chromosomal evolution in higher plants. Addison-Wesley, Reading, MA.

. 1975. The role of polyploid complexes in the evolution of North American grasslands. Taxon 24: 91-106.

StUEsSY, T. F. 1971. Systematic relationships in the white-rayed species of Melampodium (Compositae). Brittonia 23: 177-190.

Vinton, M. A. 1990. Bison grazing patterns and plant responses on Kansas tallgrass prairie. M.S. thesis, Kansas State University. Manhattan, KS.

WeAVER, J. E., AND T. J. FitzPatrick. 1934. The prairie. Ecological Monographs 4: 109-295.

ZOHARY, D., AND U. NUR. 1959. Natural triploids in the orchard grass, Dactylis glomerata $\mathrm{L}$., polyploid complex and their significance for gene flow from diploid to tetraploid levels. Evolution 13: 311-317. 